\title{
Study on physico-chemical features of water in Tarahara Fish Farm, Sunsari, Nepal
}

\author{
Ganesh Bahadur Thapa ${ }^{1}$ and Joydeb Pal ${ }^{2}$ \\ ${ }^{1}$ Department of Zoology, Central Campus of Technology, T.U., Dharan, Nepal \\ ${ }^{2}$ Department of Zoology, University of North Bengal, Darjeeling, West Bengal, India \\ *E-mail: ganeshbdr13@gmail.com
}

\begin{abstract}
Tarahara Fish Farm includes 37 large ponds as a fish super zone. Physicochemical parameters viz., air and water temperature, $\mathrm{pH}, \mathrm{DO}, \mathrm{BOD}, \mathrm{CO}_{2}$, $\mathrm{Cl}^{-}$, TA and $\mathrm{TH}$ of these ponds were studied for two years (Nov. 2008 to Oct. 2010). The air temperature had positive and significant correlation with water temperature $(\mathrm{r}=0.893, \mathrm{P}<0.01)$ but inverse and significant correlation with DO $(\mathrm{r}=-0.669 \mathrm{P}<0.05)$ and $\mathrm{TH}(\mathrm{r}=-0.673, \mathrm{P}<0.05)$. Both air and water temperature showed a decreasing trend during the winter months of November to January and again September to October in both years. Similarly, positive and significant correlation showed by $\mathrm{pH}$ with DO $(\mathrm{r}=0.660, \mathrm{P}<0.05)$ and BOD $(\mathrm{r}=0.846, \mathrm{P}<0.05)$; by free $\mathrm{CO}_{2}$ with DO $(\mathrm{r}=0.854, \mathrm{P}<0.01)$, chloride $(\mathrm{r}=0.648, \mathrm{P}<0.05)$ and TA $(\mathrm{r}=0.616, \mathrm{P}<0.05)$; by DO with TA $(\mathrm{r}=0.715, \mathrm{P}<0.01)$ and chloride $(\mathrm{r}=0.625, \mathrm{P}<0.05)$ and by TH with TA $(r=0.592, \mathrm{P}<0.05)$ but inverse and significant correlation showed by $\mathrm{pH}$ with water temperature $(\mathrm{r}=-0.671, \mathrm{P}<0.05)$; by free $\mathrm{CO}_{2}$ with BOD $(\mathrm{r}=-0.627, \mathrm{P}<0.05)$ and by DO with BOD $(\mathrm{r}=-0.810, \mathrm{P}<0.01)$. The water quality parameters were within suitable range for the fish growth and breeding with small fluctuations in different months during the first and second years. Physico-chemical parameters significantly $(\mathrm{P}<0.01 ; 0.05)$ differed between different months. However, no mass mortality of fish was recorded from this site. So, the area selected as fish super zone is fruitful to meet the expected production level of fishes and fish seeds in peripheral areas.
\end{abstract}

Key words: Fish seed, Fish super zone, Water parameters

\section{Introduction}

Tarahara Fish Farm, Sunsari is a government farm (now included in fish super zone) established in 1971 to promote the fish farming and producing fish seeds to supply private sectors along with live stocks, poultry farming and horticulture occupies about 111 ha area. Later on it was developed as regional research center under the NARC in 1994. It contains around 37 ponds covering water surface areas about 10 ha out of total fish farm areas (18 ha). Expected annual average production of food fish was about 2 ton/year but about 4 ton/year has produced in 2016-17. Besides this fish seed of Labeo rohita, Cirrhinus mrigala, Catla catla, Cyprinus carpio, Pangas sp. and Puntius sp. hatchlings: 50 lakhs/yr; fries 20 lakhs/yr and fingerlings: 2 lakhs/yr were produced according to fish scientists in Tarahara $($ Tara $=$ Terai + Hara $=$ Hariyali $)$.

The physico-chemical parameters mainly air and water temperature, transparency, $\mathrm{pH}, \mathrm{DO}$, BOD, free $\mathrm{CO}_{2}$, chloride, TA and TH of water bodies influence the aquatic organisms in 
various ways directly or indirectly which determine the hydrological condition of water body and any alteration of it influences the outbreak of diseases and production level of fishes. In fish farming, fish disease is one of the major constraints for the adequate production. Fish disease is a global problem affecting fresh water and marine fish, wild, cultured, sport fish and even ornamental fish with large scale mortalities (Trust, 1986). The present production level is still much below the potentiality of existing water resources. Nepal government has given priority to aquaculture development by establishing the fish super zones for high production to fulfill the protein demand of the country. The use of artificial feed, fertilizer in the semi-intensive and intensive culture to increase production may adversely alter the physico-chemical properties of water and other environmental conditions that generate the diseases outbreak.

However, McEachern (1994) reported $8.4 \mathrm{pH}, 0.03 \mathrm{mg} / \mathrm{L}$ phosphate and $8.5 \mathrm{mg} / \mathrm{L}$ dissolved oxygen in Narayani, a lowland $(<1000 \mathrm{~m})$ river of Nepal. Aryal and Lacoul (1996) studied water quality and diversity of diatoms in Punyamati river. Sharma (1996) reported quite suitable physico-chemical characteristics of the Koshi River. Shrestha et al. (2009) reported that the water quality parameters of Tamor River. Niroula et al. (2010) revealed more seasonal fluctuations in turbidity, carbon dioxide and chloride content were observed in Betana pond, Eastern Nepal. Thapa Chhetry and Pal (2011) studied the physico-chemical parameters of Koshi river. Bhatt and Khanal (2011) reported that the increase in $\mathrm{pH}$ of water appeared to be associated with increasing use of alkaline detergents in residential areas. Thapa and Pal (2012) found maximum and minimum variation and correlation between different physico-chemical parameters in Baidya Fish Farm and Itahari fish ponds. Thapa and Pal (2014) mentioned the physico-chemical parameters of Singhia and Budhi Rivers. Extensive work in physico-chemical characters of water has not been done yet in Tarahara, so the study will provide information about the quality of pond waters whether fit or not for successful fish/seed productions.

\section{Materials and Methods}

Tarahara Fish Farm is located at latitude $26^{\circ} 42^{\prime} 05.77^{\prime \prime N}$ and Longitude $87^{\circ} 16^{\prime} 38.50^{\prime \prime} \mathrm{E}$ in Sunsari district (Fig. 1).

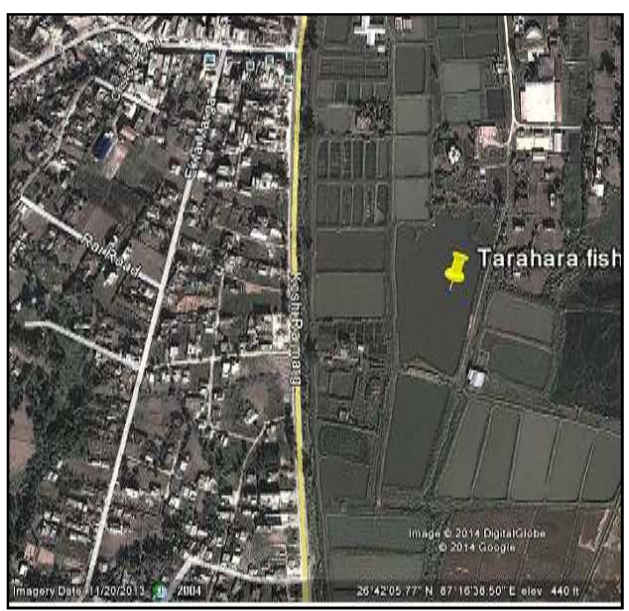

Figure 1. Tarahara Fish Farm, Sunsari.

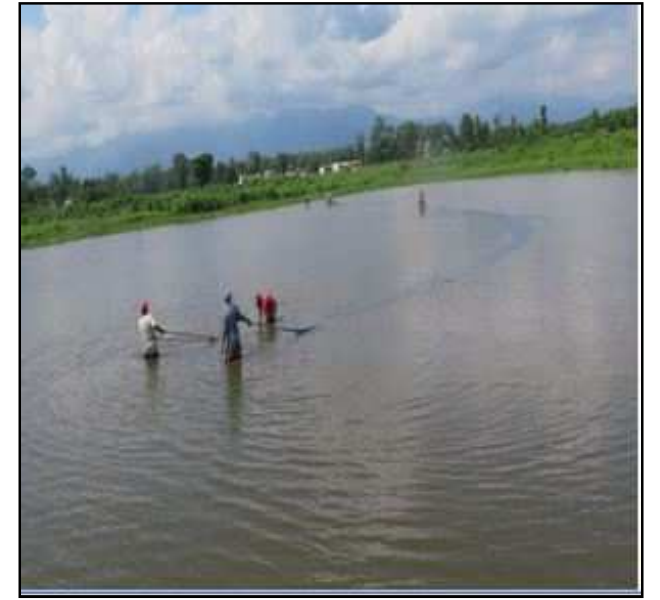


Water collection was done in between 8.00-11.00 A.M. in air tights bottles. Temperature was estimated on the site by glass thermometer. The $\mathrm{pH}$ of water was estimated on the site by Hanna's pocket $\mathrm{pH}$ meter. All other physico-chemical analysis of water like dissolved oxygen (DO), biological oxygen demand (BOD), free carbon dioxide (free $\mathrm{CO}_{2}$ ) in site ,chloride ions $\left(\mathrm{Cl}^{-}\right)$, total alkalinity (TA) and total hardness $(\mathrm{TH})$ were determined for two years (Nov. 2008 to Oct. 2010) following standard methods (Trivedy \& Goel, 1986; APHA, AWWA \& WEF, 2012).

Standard deviation, correlation coefficient were calculated by using Microsoft excel statistical function of computer software. The significance of correlation coefficient was tested by applying t-test by using SPSS-V20 computer software.

\section{Results and Discussion}

Results of the air temperature and physico-chemical parameters of water of Tarahara Fish Farm are shown in Table 1 and 2. Table 1 shows the result of air temperature and physicochemical parameters of water of the first year (Nov. 2008 to Oct. 2009) study period. Table 2 shows the results of air temperature and physico-chemical parameters of water of the second year (Nov. 2009 to Oct. 2010) study period. Table 3 shows the correlation coefficient ( $\mathrm{r}$ ) of air temperature and different physico-chemical parameters of water. The figs. 2, 3 and 4 show histograms of the monthly variations of different physico-chemical parameters of water at in the first year (Nov. 2008 to Oct. 2009) and the second year (Nov. 2009 to Oct. 2010) study periods.

\section{Air temperature}

The minimum air temperature was $19.75 \pm 0.645^{\circ} \mathrm{C}$ in the month of December and maximum was $31.62 \pm 0.478^{\circ} \mathrm{C}$ in April during the first year study period (Table 1). The minimum air temperature was $17.52 \pm 0.445^{\circ} \mathrm{C}$ in the December and maximum was $30.5 \pm 0.386^{\circ} \mathrm{C}$ in September during the second year study period (Table 2).

The temperature showed a declining trend during the winter months of November to January in both the first and second year. Decreasing trend was also observed during the months of September to October in both years (Tables 1,2). The air temperature had positive and significant correlation with water temperature $(\mathrm{r}=0.893, \mathrm{P}<0.01)$ but inverse and significant correlation with DO $(\mathrm{r}=-0.669 \mathrm{P}<0.05)$ and $\mathrm{TH}(\mathrm{r}=-0.673, \mathrm{P}<0.05)$ (Table 3). The highest air temperature was recorded in the month of April in first year and in September in the second year. It was mainly due to geographical positions and weather conditions. Chakraborty et al. (1959) and Rawat et al. (1995) also obtained strong positive significant correlation between air and water temperatures.

\section{Water temperature}

The lowest surface water temperature was $15.3 \pm 0.489^{\circ} \mathrm{C}$ in the month of December and highest $29.12 \pm 0.275^{\circ} \mathrm{C}$ in the month of April during the first year study period (Table 1). The maximum water temperature was $30.25 \pm 0.347^{\circ} \mathrm{C}$ in the month of September and the minimum $17.31 \pm 0.459^{\circ} \mathrm{C}$ in the month of December during the second year study period. The temperature showed a decreasing trend during the winter months of November to January in both the years. Decreasing trend was also observed during the months of September to October in both years (Tables 1, 2; Fig. 2). The water temperature had 
positive and significant correlation with air temperature $(\mathrm{r}=0.893, \mathrm{P}<0.01)$ but inverse and significant correlation with DO $(r=-0.704, \mathrm{P}<0.05)$ and $\mathrm{TH}(\mathrm{r}=-0.909, \mathrm{P}<0.01)$ (Table 3$)$.

Highest value was recorded in summer might be due to high air temperature and greater light penetration. A little lower water temperature was recorded at rainy season in comparison to that during summer. It might be due to high turbidity, high volume of water and greater velocity of water in rainy season. Bose and Gorai (1993) reported negative significant correlation between water temperature and dissolved oxygen.

\section{pH}

The minimum $\mathrm{pH}$ was $6.67 \pm 0.125$ in the month of April and maximum $8.62 \pm 0.095$ in January, during the first year study period (Table 1). The minimum $\mathrm{pH}$ was $7.08 \pm 0.058$ in October and maximum 10.02 \pm 0.276 was in February during the second year study period (Table 2). $\mathrm{pH}$ had positive and significant correlation with DO $(\mathrm{r}=0.660, \mathrm{P}<0.05)$, BOD $(\mathrm{r}$ $=0.846, \mathrm{P}<0.05)$ but inverse and significant correlation with temperature of air $(\mathrm{r}=-0.523$, $\mathrm{P}<0.10)$ and temperature of water $(\mathrm{r}=-0.671, \mathrm{P}<0.05)$ (Table 3). Hutchinson et al. (1992) have shown that the higher $\mathrm{pH}$ is associated with the phytoplankton maxima. The minimum $\mathrm{pH}$ recorded in summer may be due to low photosynthesis. Several workers have reported low $\mathrm{pH}$ during the low photosynthesis due to the formation of carbonic acid (Bais et al., 1995). But, Gautam (1990) reported highest $\mathrm{pH}$ in summer and lowest in rainy season. The $\mathrm{pH}$ showed positive and significant correlation with dissolved oxygen at the site. Rawat $e t$ al. (1995) reported positive correlation with TA $(\mathrm{r}=0.523, \mathrm{P}<0.05)$ and inverse correlation with water temperature.

\section{Free carbon dioxide}

The maximum free $\mathrm{CO}_{2}$ was $135.6 \pm 1.356 \mathrm{mg} / \mathrm{L}$ in the month of June and minimum was $16.75 \pm 0.952 \mathrm{mg} / \mathrm{L}$ in the month of September during the first year (Table 1). During the second year, the maximum free $\mathrm{CO}_{2}$ was $114.58 \pm 1.356 \mathrm{mg} / \mathrm{L}$ in the month of June and minimum was $12.24 \pm 0.584 \mathrm{mg} / \mathrm{L}$ in May (Table 1). Free $\mathrm{CO}_{2}$ showed positive and significant correlation with DO $(\mathrm{r}=0.854, \mathrm{P}<0.01)$, chloride $(\mathrm{r}=0.648, \mathrm{P}<0.05)$ and TA $(\mathrm{r}=0.616, \mathrm{P}<0.05)$ but had an inverse and significant with BOD $(\mathrm{r}=-0.627, \mathrm{P}<0.05)($ Table 3 ). In this study the minimum free $\mathrm{CO}_{2}$ was found in winter season. Pahwa and Mehrotra (1966) observed inverse correlation of free $\mathrm{CO}_{2}$ with DO. Gautam (1990) and Pandey and Lal (1995) also found minimum free carbon dioxide in winter season.

\section{Dissolved oxygen}

The maximum dissolved oxygen was $8.92 \pm 0.221 \mathrm{mg} / \mathrm{L}$ in the month of January and the minimum was $4.86 \pm 0.079 \mathrm{mg} / \mathrm{L}$ in the month of August during the first year study period (Table 1). In the second year, the maximum dissolved oxygen was $10.16 \pm 0.215 \mathrm{mg} / \mathrm{L}$ in February and minimum $2.94 \pm 0.305 \mathrm{mg} / \mathrm{L}$ was recorded in September (Table 2). The DO showed positive and significant correlation with TA $(\mathrm{r}=0.715, \mathrm{P}<0.01), \mathrm{CO}_{2}(\mathrm{r}=0.854$, $\mathrm{P}<0.01)$, chloride $(\mathrm{r}=0.625, \mathrm{P}<0.05)$ and $\mathrm{pH}(\mathrm{r}=0.660, \mathrm{P}<0.05)$ but inverse and significant correlation with air temperature $(\mathrm{r}=-0.669, \mathrm{P}<0.05)$, water temperature $(\mathrm{r}=-0.704$, $\mathrm{P}<0.05)$ and BOD $(\mathrm{r}=-0.810, \mathrm{P}<0.01)$ (Table 3$)$. The maximum dissolved oxygen found in winter season may be due to low temperature. Similar observations were found by Moitra and Bhattacharya (1965). The minimum dissolved oxygen was found in summer due to high temperature, and higher microbial demand for oxygen in decomposition of 
suspended organic matter (Bhowmick \& Singh, 1985; Palharya \& Malviya, 1988). Elmore and West (1961) stated that an increase in temperature of water resulted in the decrease of dissolved oxygen content of water. Bose and Gorai (1993) also reported inverse and significant correlation of dissolved oxygen with water temperature. Jindal and Kumar (1993) reported inverse correlation of dissolved oxygen with water temperature.

\section{Biological oxygen demand}

The maximum biological oxygen demand was $5.31 \pm 0.082 \mathrm{mg} / \mathrm{L}$ in January and minimum was $0.47 \pm 0.145 \mathrm{mg} / \mathrm{L}$ in May during the first year study period (Table 1). During the second year, the maximum biological oxygen demand was $7.14 \pm 0.263 \mathrm{mg} / \mathrm{L}$ in December and minimum was $0.45 \pm 0.075 \mathrm{mg} / \mathrm{L}$ in November (Table 2). It had positive and significant correlation with $\mathrm{pH}(\mathrm{r}=0.846, \mathrm{P}<0.01)$ but inverse and significant correlation with dissolved oxygen $(\mathrm{r}=-0.810, \mathrm{P}<0.01)$ (Table 3$)$. Similar observations were also made by Singh (1995). Barat and Jha (2002) also reported inverse correlation of BOD with dissolved oxygen. BOD showed positive and significant correlation with air temperature, water temperature and free $\mathrm{CO}_{2}$ were inverse and significant correlation with $\mathrm{pH}$ and $\mathrm{DO}$.

\section{Chloride}

The maximum chloride was $12.98 \pm 0.416 \mathrm{mg} / \mathrm{L}$ in January and minimum was $5.2 \pm 0.288$ $\mathrm{mg} / \mathrm{L}$ in October during the first year study period (Table 1). During the second year, the maximum chloride was $9.02 \pm 0.525 \mathrm{mg} / \mathrm{L}$ in the month of June and minimum was $1.06 \pm 0.035 \mathrm{mg} / \mathrm{L}$ in April (Table 2). It had a positive and significant correlation with DO $(\mathrm{r}=$ $0.625, \mathrm{P}<0.05)$ and free $\mathrm{CO}_{2}(\mathrm{r}=0.648, \mathrm{P}<0.05)($ Table 3$)$. In this site maximum chloride was recorded in winter season which might be due to more contamination by organic matters. Swarup and Singh (1979) also reported an increase in chloride during summer. Minimum quantity of chloride in rainy season might be due to dilution by rain water.

\section{Total alkalinity}

The maximum total alkalinity was $202.50 \pm 5.802 \mathrm{mg} / \mathrm{L}$ in the month of January and minimum was $103.40 \pm 0.469 \mathrm{mg} / \mathrm{L}$ in the month of September during the first year study period (Table 1; Fig. 3). During the second year, the maximum total alkalinity was $215.03 \pm 1.089 \mathrm{mg} / \mathrm{L}$ in the month of March and minimum was $72.74 \pm 1.092 \mathrm{mg} / \mathrm{L}$ in the month of December (Table 2, Fig. 3). It had positive and significant correlation with DO $(\mathrm{r}=0.715, \mathrm{P}<0.01), \mathrm{CO}_{2}(\mathrm{r}=0.616, \mathrm{P}<0.05)$ and $\mathrm{TH}(\mathrm{r}=0.592, \mathrm{P}<0.05)($ Table 3$)$. Total alkalinity showed decreasing trend from June to September. The values in the month of June $(125.62 \pm 0.805 \mathrm{mg} / \mathrm{L})$ was significantly decreased $(\mathrm{P}<0.01)$ as compared to May $(167.12 \pm 0.689 \mathrm{mg} / \mathrm{L})$ in the first year study (Table 1 ; Fig. 3). In the second year, decreasing trend was seen from June to October. The value of June $(124.22 \pm 0.995 \mathrm{mg} / \mathrm{L})$ was significantly decreased $(\mathrm{P}<0.01)$ as compared to May $(136.40 \pm 1.642 \mathrm{mg} / \mathrm{L})($ Table 2 ; Fig. 3). It remained low for five months from June to October in both years. Water bodies having total alkalinity from 40 to $90 \mathrm{mg} / \mathrm{L}$ is considered as medium productive and above $90 \mathrm{mg} / \mathrm{L}$ as highly productive (Jhingran, 1991). It showed that the study area is suitable for aquatic flora and fauna production. Total alkalinity showed positive and significant correlation with total hardness and chloride at the site. Barat and Jha (2002) also reported positive and significant correlation of total alkalinity with hardness. Chakraborty et al. (1959), Singh (1990) and Mishra et al. (1998) also reported maximum total alkalinity during winter. 


\section{Total hardness}

The maximum total hardness was $164.4 \pm 1.478 \mathrm{mg} / \mathrm{L}$ in January and minimum was $83.6 \pm 0.585 \mathrm{mg} / \mathrm{L}$ in the month of July during the first year study period (Table 1; Fig. 4). During the second year, the maximum total hardness was recorded $163.26 \pm 1.023 \mathrm{mg} / \mathrm{L}$ in February and minimum $35.64 \pm 1.578 \mathrm{mg} / \mathrm{L}$ in the month of January (Table 2; Fig. 4). It had positive and significant correlation with TA $(r=0.592, \mathrm{P}<0.05)$ but inverse and significant correlation with air temperature $(\mathrm{r}=-0.673, \mathrm{P}<0.05)$ and water temperature $(\mathrm{r}=-0.909$, $\mathrm{P}<0.01$ ) (Table 3). The hardness showed a decreasing trend from the months of April to August and increased slightly during the months of September and October but the values were less than that of during the month of April. The values in April $(101.2 \pm 0.776 \mathrm{mg} / \mathrm{L})$ showed significant decrease $(\mathrm{p}<0.01)$ as compared to March $(146.14 \pm 0.985 \mathrm{mg} / \mathrm{L})$ in the first year (Table 1; Fig. 4). It also showed decreasing trend from March 2010. The values in March $(156.420 \pm 0.675 \mathrm{mg} / \mathrm{L})$ was significantly lower $(\mathrm{P}<0.01)$ as compared to February $(163.26 \pm 1.023 \mathrm{mg} / \mathrm{L})$ in the second year (Table 2; Fig. 4). It remained low for seven months from April to October in the first year and for eight months from March to October in the second year. Minimum quantity in rainy season may be due to more dilution of water (Patralekh, 1994).The maximum total hardness in winter season might be due to low volume of water and slow current of water. Mishra et al. (1999) obtained similar results.

Table 1. Water parameters of Tarahara Farm, from Nov. 2008 to October 2009. (Mean \pm S.D., N=5).

\begin{tabular}{|c|c|c|c|c|c|c|c|c|c|c|c|c|}
\hline \multirow[t]{2}{*}{ Parameters } & \multicolumn{12}{|c|}{ Months } \\
\hline & Nov & Dec & Jan & Feb & Mar & Apr & May & Jun & Jul & Aug & Sept & Oct \\
\hline \multirow{3}{*}{$\begin{array}{l}\text { Air Temp. } \\
\left({ }^{\circ} \mathrm{C}\right)\end{array}$} & 21.25 & 19.75 & 20.87 & 24.75 & 29.25 & 31.62 & 29.12 & 29.25 & 25.75 & 29.37 & 29.25 & 27.45 \\
\hline & \pm 0.64 & \pm 0.64 & \pm 1.10 & \pm 0.64 & \pm 0.64 & \pm 0.478 & \pm 0.62 & \pm 0.288 & \pm 0.64 & \pm 0.47 & \pm 0.28 & \pm 0.42 \\
\hline & 5 & 5 & 8 & 5 & 5 & & 9 & & 5 & 8 & 8 & 0 \\
\hline \multirow{3}{*}{$\begin{array}{l}\text { Water } \\
\text { Temp. }\left({ }^{\circ} \mathrm{C}\right)\end{array}$} & 18.75 & 15.3 & 18.75 & 21.5 & 23.57 & 29.12 & 27.07 & 27.45 & 27.07 & 27.12 & 27.25 & 25.27 \\
\hline & \pm 0.22 & \pm 0.48 & \pm 0.28 & \pm 0.40 & \pm 0.43 & \pm 0.275 & \pm 0.25 & \pm 0.42 & \pm 0.25 & \pm 0.27 & \pm 0.64 & \pm 0.49 \\
\hline & 8 & 9 & 8 & 8 & 4 & & & & & 5 & 5 & 9 \\
\hline \multirow[t]{3}{*}{ pH } & 7.9 & 8.05 & 8.62 & 8.12 & 7.325 & 6.67 & 8.12 & 8.2 & 7.05 & 7.12 & 8.2 & 7.62 \\
\hline & \pm 0.08 & \pm 0.12 & \pm 0.09 & 0.095 & \pm 0.09 & \pm 0.125 & \pm 0.62 & \pm 0.081 & \pm 0.05 & \pm 0.27 & \pm 0.21 & \pm 0.47 \\
\hline & 9 & 9 & 5 & \pm & 5 & & 9 & & 7 & 5 & 6 & 8 \\
\hline \multirow{3}{*}{$\begin{array}{l}\text { Free CO } \mathrm{CO}_{2} \\
(\mathrm{mg} / \mathrm{L})\end{array}$} & 21.63 & 55.02 & 91.05 & 126.3 & 135.1 & 101.96 & 93.15 & 135.6 & 113.3 & 49.13 & 16.75 & 38.16 \\
\hline & \pm 1.20 & \pm 1.27 & \pm 1.07 & 5 & 2 & \pm 0.416 & \pm 0.58 & \pm 1.356 & 5 & \pm 1.3 & \pm 0.95 & \pm 0.62 \\
\hline & 3 & 5 & 8 & \pm 0.86 & \pm 0.85 & & 0 & & \pm 0.85 & & 2 & 3 \\
\hline \multirow{3}{*}{$\begin{array}{l}\text { DO } \\
(\mathrm{mg} / \mathrm{L})\end{array}$} & 5.71 & 5.84 & 8.92 & 8.61 & 7.86 & 8.1 & 7.04 & 7.83 & 8.90 & 4.86 & 5.45 & 5.75 \\
\hline & \pm 0.33 & \pm 0.07 & \pm 0.22 & \pm 0.11 & \pm 0.35 & \pm 0.127 & \pm 0.22 & \pm 0.009 & \pm 0.55 & \pm 0.07 & \pm 0.24 & \pm 0.36 \\
\hline & 5 & 9 & 1 & 5 & 4 & & 5 & & 3 & 9 & 5 & 5 \\
\hline \multirow{3}{*}{$\begin{array}{l}\text { BOD } \\
(\mathrm{mg} / \mathrm{L})\end{array}$} & 2.91 & 2.30 & 5.31 & 3.67 & 0.65 & 1.74 & 0.47 & 0.54 & 2.35 & 2.78 & 3.5 & 3.35 \\
\hline & \pm 0.14 & \pm 0.06 & \pm 0.08 & \pm 0.23 & \pm 0.25 & \pm 0.057 & \pm 0.14 & \pm 0.235 & \pm 0.08 & \pm 0.36 & \pm 0.32 & \pm 0.34 \\
\hline & 5 & 7 & 2 & 8 & 3 & & 5 & & 2 & 5 & 5 & 6 \\
\hline \multirow{3}{*}{$\begin{array}{l}\text { Chloride } \\
\text { (mg/L) }\end{array}$} & 8.2 & 5.3 & 12.98 & 9.88 & 11.32 & 12.06 & 8.46 & 12.2 & 8.41 & 9.96 & 6.21 & 5.2 \\
\hline & \pm 0.33 & \pm 0.08 & \pm 0.41 & \pm 0.33 & \pm 0.22 & \pm 0.132 & \pm 0.12 & \pm 0.629 & \pm 0.14 & \pm 0.54 & \pm 0.22 & \pm 0.28 \\
\hline & 2 & 2 & 6 & 4 & 1 & & 9 & & 5 & 6 & 3 & 8 \\
\hline \multirow{4}{*}{$\begin{array}{l}\text { Total Alkali } \\
(\mathrm{mg} / \mathrm{L})\end{array}$} & 147.9 & 128.7 & 202.5 & 194.9 & 176.8 & 157.7 & 167.1 & 125.62 & 135.8 & 118.0 & 103.4 & 133.0 \\
\hline & 6 & 2 & \pm 5.80 & 5 & 2 & \pm 0.877 & 2 & \pm 0.805 & \pm 0.58 & 7 & \pm 0.46 & 2 \\
\hline & \pm 1.86 & \pm 1.11 & 2 & \pm 1.96 & \pm 1.18 & & \pm 0.68 & $*$ & 5 & \pm 0.44 & 9 & \pm 0.69 \\
\hline & 0 & 2 & & 2 & 9 & & 9 & & & 9 & & $\frac{4}{4}$ \\
\hline \multirow{4}{*}{$\begin{array}{l}\text { Total } \\
\text { Hardness } \\
(\mathrm{mg} / \mathrm{L})\end{array}$} & 138.7 & 157.0 & 164.4 & 148.6 & 146.1 & 101.2 & 96.32 & 91.2 & 83.6 & 92.88 & 108.2 & 118.2 \\
\hline & 2 & 8 & \pm 1.47 & \pm 1.03 & 4 & \pm 0.776 & \pm 1.74 & \pm 1.558 & \pm 0.99 & \pm 0.75 & 5 & 3 \\
\hline & \pm 2.12 & \pm 1.32 & 8 & 6 & \pm 0.98 & $*$ & 5 & & 8 & 6 & \pm 0.95 & \pm 0.77 \\
\hline & 5 & 5 & & & 5 & & & & & & 5 & 9 \\
\hline
\end{tabular}

* Significant differences at $1 \%$ level, ** Significant differences at $5 \%$ level. 
Table 2. Water parameters of Tarahara Fish Farm, Sunsari studied from Nov. 2009 to October 2010. (Mean \pm S.D., $\mathrm{N}=5$ ).

\begin{tabular}{|c|c|c|c|c|c|c|c|c|c|c|c|c|}
\hline \multirow[t]{2}{*}{ Parameters } & \multicolumn{12}{|c|}{ Months } \\
\hline & Nov & Dec & Jan & Feb & Mar & Apr & May & Jun & Jul & Aug & Sept & Oct \\
\hline \multirow{3}{*}{$\begin{array}{l}\text { Air Temp. } \\
\left({ }^{\circ} \mathrm{C}\right)\end{array}$} & 19.12 & 17.52 & 18.37 & 21.35 & 28.25 & 28.02 & 24.13 & 25.15 & 29.5 & 29.17 & 30.5 & 27.85 \\
\hline & 0.3 & \pm 0.4 & \pm .60 & \pm 0.5 & \pm 0.7 & \pm 0.4 & \pm 0.2 & \pm 0.2 & \pm 0.6 & \pm 0.3 & \pm 0.3 & \pm 0.6 \\
\hline & & 45 & 8 & 45 & 45 & 78 & 29 & 78 & 35 & 78 & 86 & 20 \\
\hline \multirow{3}{*}{$\begin{array}{l}\text { W Temp. } \\
\left({ }^{\circ} \mathrm{C}\right)\end{array}$} & 21.26 & 17.31 & 17.45 & 19.20 & 25.26 & 27.12 & 26.57 & 28.05 & 28.65 & 30.12 & 30.25 & 25.87 \\
\hline & & \pm 0.4 & \pm 0.2 & \pm 0.2 & \pm 0.3 & \pm 0.2 & \pm 0.2 & \pm 0.4 & \pm 0.2 & \pm 0.2 & \pm 0.3 & \pm 0.5 \\
\hline & 25 & 59 & 46 & 18 & 35 & 75 & 51 & 2 & 54 & 35 & 47 & 78 \\
\hline \multirow[t]{3}{*}{ pH } & 7.33 & 8.68 & 7.82 & 10.02 & 7.72 & 7.76 & 7.51 & 7.62 & 8.05 & 7.81 & 7.64 & 7.08 \\
\hline & & \pm 0.4 & \pm 0.5 & \pm 0.2 & \pm 0.0 & \pm 0.3 & \pm 0.4 & \pm 0.2 & \pm 0.0 & \pm 0.0 & \pm 0.2 & \pm 0.0 \\
\hline & 85 & 26 & 65 & 76 & 76 & 25 & 27 & 81 & 68 & 78 & 16 & 58 \\
\hline \multirow{3}{*}{$\begin{array}{l}\text { Free CO } \mathrm{CO}_{2} \\
(\mathrm{mg} / \mathrm{L})\end{array}$} & .52 & 15.12 & 47.52 & 16.03 & 15.12 & 14.56 & 12.24 & 114.5 & 18.35 & 16.14 & 16.75 & 15.68 \\
\hline & & \pm 1.2 & \pm 1.0 & \pm 0.9 & \pm 0.8 & \pm 0.8 & \pm 0.5 & \pm 1.3 & \pm 0.9 & \pm 1.3 & \pm 0.6 & \pm 0.3 \\
\hline & 25 & 05 & 78 & 65 & 53 & 17 & 84 & 56 & 15 & 25 & 52 & 23 \\
\hline \multirow[t]{3}{*}{ DO (mg/L) } & 4.48 & 8.48 & 8.81 & 10.16 & 4.64 & 7.71 & 3.04 & 3.31 & 4.81 & 4.65 & 2.94 & 4.22 \\
\hline & & \pm 0.0 & \pm 0.2 & \pm 0.2 & \pm 0.3 & \pm 0.1 & \pm 0.2 & \pm 0.0 & \pm 0.3 & \pm 0.0 & \pm 0.3 & \pm 0.2 \\
\hline & 15 & 67 & 29 & 15 & 08 & 25 & 32 & 58 & 73 & 79 & 05 & 65 \\
\hline \multirow[t]{3}{*}{ BOD $(\mathrm{mg} / \mathrm{L})$} & & 7.14 & 3.38 & 7.01 & 2.68 & 5.02 & 2.04 & 1.75 & 2.85 & 0.82 & 1.03 & 0.51 \\
\hline & \pm 0.0 & \pm 0.2 & \pm 0.1 & \pm 0.2 & \pm 0.1 & \pm 0.0 & \pm 0.1 & \pm 0.2 & \pm 0.0 & \pm 0.3 & \pm 0.2 & \pm 0.2 \\
\hline & 75 & 63 & 72 & 41 & 58 & 89 & 65 & 45 & 64 & 25 & 27 & 43 \\
\hline \multirow{3}{*}{$\begin{array}{l}\text { Chloride } \\
\text { (mg/L) }\end{array}$} & 2.70 & 2.58 & 4.21 & 4.02 & 3.12 & 1.06 & 4.14 & 9.02 & 5.11 & 4.01 & 6.10 & 5.03 \\
\hline & & \pm 0.1 & \pm 0.3 & \pm 0.3 & \pm 0.3 & \pm 0.0 & \pm 0.1 & \pm 0.5 & \pm 0.0 & \pm 0.3 & \pm 0.1 & \pm 0.2 \\
\hline & & 84 & 17 & 14 & 22 & 35 & 32 & 25 & 97 & 74 & 52 & 38 \\
\hline \multirow{4}{*}{$\begin{array}{l}\text { Total Alkalin } \\
\text { (mg/L) }\end{array}$} & 144.0 & 72.74 & 180.2 & 117.5 & 215.0 & 195.5 & 136.4 & 124.2 & 119.7 & 101.2 & 118.7 & 117.8 \\
\hline & 8 & \pm 1.0 & 5 & 5 & 3 & 7 & 0 & 2 & \pm 0.8 & 3 & 5 & 6 \\
\hline & \pm 1.6 & 92 & \pm 4.5 & \pm 1.8 & \pm 1.0 & \pm 1.8 & \pm 1.6 & \pm 0.9 & 87 & \pm 0.8 & \pm 0.5 & \pm 0.8 \\
\hline & 63 & & 32 & 76 & 89 & 77 & 42 & $9 *$ & & 49 & 59 & 93 \\
\hline \multirow{4}{*}{$\begin{array}{l}\text { Total Hardn } \\
(\mathrm{mg} / \mathrm{L})\end{array}$} & 138.7 & 116.8 & 35.64 & 163.2 & 156.4 & 152.3 & 97.02 & 102.9 & 93.06 & 83.16 & 93.01 & 110.8 \\
\hline & 2 & 2 & \pm 1.5 & 6 & 2 & 2 & \pm 1.3 & 5 & \pm 1.0 & \pm 0.3 & \pm 0.9 & 5 \\
\hline & \pm 2.1 & \pm 1.7 & 78 & \pm 1.0 & \pm 0.6 & \pm 1.4 & 42 & \pm 0.9 & 97 & 56 & 78 & \pm 0.7 \\
\hline & 25 & 21 & & 23 & $7 *$ & 45 & & 06 & & & & 19 \\
\hline
\end{tabular}

* Significant differences at $1 \%$ level, ** Significant differences at $5 \%$ level.

Table 3. Pearson's Correlation Coefficient (r) for water parameters of Tarahara Fish Farm (average of the corresponding month values) from Nov. 2008 to Oct. $2010 .(\mathrm{N}=12$, d.f. $=11)$

\begin{tabular}{|c|c|c|c|c|c|c|c|c|c|}
\hline & & $\begin{array}{c}\text { Water } \\
\text { Temp } \\
\left({ }^{\circ} \mathrm{C}\right) \\
\end{array}$ & $\mathbf{p H}$ & $\begin{array}{c}\text { Free } \\
\mathrm{CO}_{2} \\
(\mathrm{mg} / \mathrm{L})\end{array}$ & $\begin{array}{c}\text { DO } \\
(\mathrm{mg} / \mathrm{L})\end{array}$ & $\begin{array}{c}\text { BOD } \\
(\mathrm{mg} / \mathrm{L})\end{array}$ & $\begin{array}{c}\text { Chloride } \\
\text { (mg/L) }\end{array}$ & $\begin{array}{c}\text { Total } \\
\text { alkali } \\
\text { (mg/L) }\end{array}$ & $\begin{array}{c}\text { Total } \\
\text { hard } \\
(\mathrm{mg} / \mathrm{L}) \\
\end{array}$ \\
\hline \multirow{2}{*}{$\begin{array}{l}\text { Air Temp } \\
\left({ }^{\circ} \mathrm{C}\right)\end{array}$} & P corr. & $.893^{*}$ & -.523 & .241 & $-.669^{* *}$ & -.373 & .308 & -.199 & $-.673^{* * *}$ \\
\hline & $\operatorname{Sig}(2-t)$ & .000 & .081 & .450 & .048 & .232 & .331 & .535 & .017 \\
\hline \multirow{2}{*}{$\begin{array}{l}\text { Water } \\
\text { Temp. } \\
\left({ }^{\circ} \mathrm{C}\right) \\
\end{array}$} & P corr. & 1 & $-.571^{* *}$ & .148 & $-.704^{* * *}$ & -.299 & .148 & -.429 & $-.909^{*}$ \\
\hline & Sig.(2-t) & & .051 & .647 & .011 & .346 & .647 & .165 & .000 \\
\hline \multirow{2}{*}{ pH } & P corr. & & 1 & -.219 & $.660^{* *}$ & $.846^{*}$ & -.053 & .315 & .515 \\
\hline & Sig.(2-t) & & & .495 & .019 & .001 & .870 & .318 & .086 \\
\hline \multirow{2}{*}{$\begin{array}{l}\text { Free } \mathrm{CO}_{2} \\
(\mathrm{mg} / \mathrm{L})\end{array}$} & P corr. & & & 1 & $.854^{*}$ & $-.627^{* *}$ & $.648^{* * *}$ & $.616^{* *}$ & -.049 \\
\hline & Sig.(2-t) & & & & .000 & .051 & .023 & .039 & .880 \\
\hline
\end{tabular}




\begin{tabular}{|c|c|c|c|c|c|}
\hline $\begin{array}{l}\mathrm{DO} \\
(\mathrm{mg} / \mathrm{L})\end{array}$ & $\begin{array}{l}\text { P corr. } \\
\text { Sig. }(2-t)\end{array}$ & $\begin{array}{l}.810^{*} \\
.001\end{array}$ & $\begin{array}{l}.625^{* * *} \\
.030\end{array}$ & $\begin{array}{l}.715^{*} \\
.009\end{array}$ & $\begin{array}{l}.155 \\
.631\end{array}$ \\
\hline BOD & P corr. & 1 & -.044 & .028 & .316 \\
\hline$(\mathrm{mg} / \mathrm{L})$ & Sig. $(2-t)$ & & .892 & .930 & .317 \\
\hline $\begin{array}{l}\text { Chloride } \\
\text { (mg/L) }\end{array}$ & $\begin{array}{l}\text { P corr. } \\
\text { Sig. (2-t) }\end{array}$ & & $\begin{array}{c}-.624^{* *} \\
.046\end{array}$ & $\begin{array}{l}.555 \\
.061\end{array}$ & $\begin{array}{l}.026 \\
.935\end{array}$ \\
\hline Total & P corr. & & & 1 & $.592^{* *}$ \\
\hline $\begin{array}{l}\text { alkal } \\
(\mathbf{m g} / \mathbf{L})\end{array}$ & Sig.(2-t) & & & & .043 \\
\hline $\begin{array}{l}\text { Total } \\
\text { hard } \\
(\mathrm{mg} / \mathrm{L})\end{array}$ & $\begin{array}{l}\text { P corr. } \\
\text { Sig.(2-t) }\end{array}$ & & & & 1 \\
\hline
\end{tabular}

*Significant at $1 \%$ level $(\mathrm{P}<0.01), * *$ Significant at $5 \%$ level $(\mathrm{P}<0.05)$ and values not marked denote non-significant correlation.

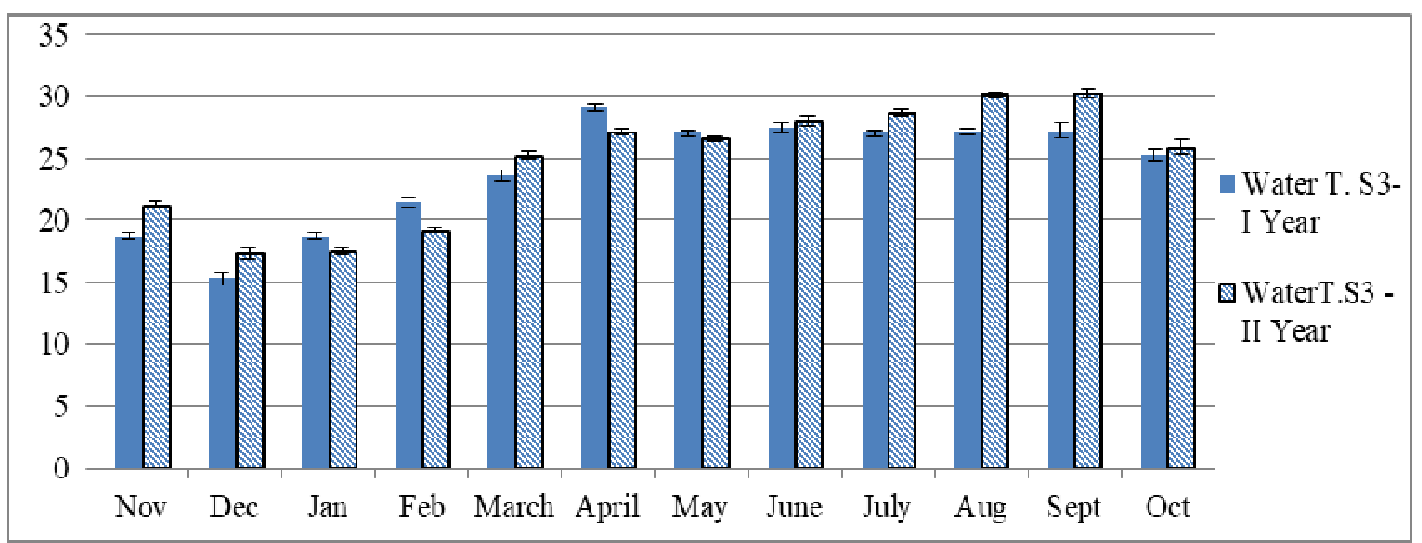

Figure 2. Monthly variations in water temperature at Tarahara Fish Farm during the first and second year study periods (Nov. 2008- Oct. 2010).

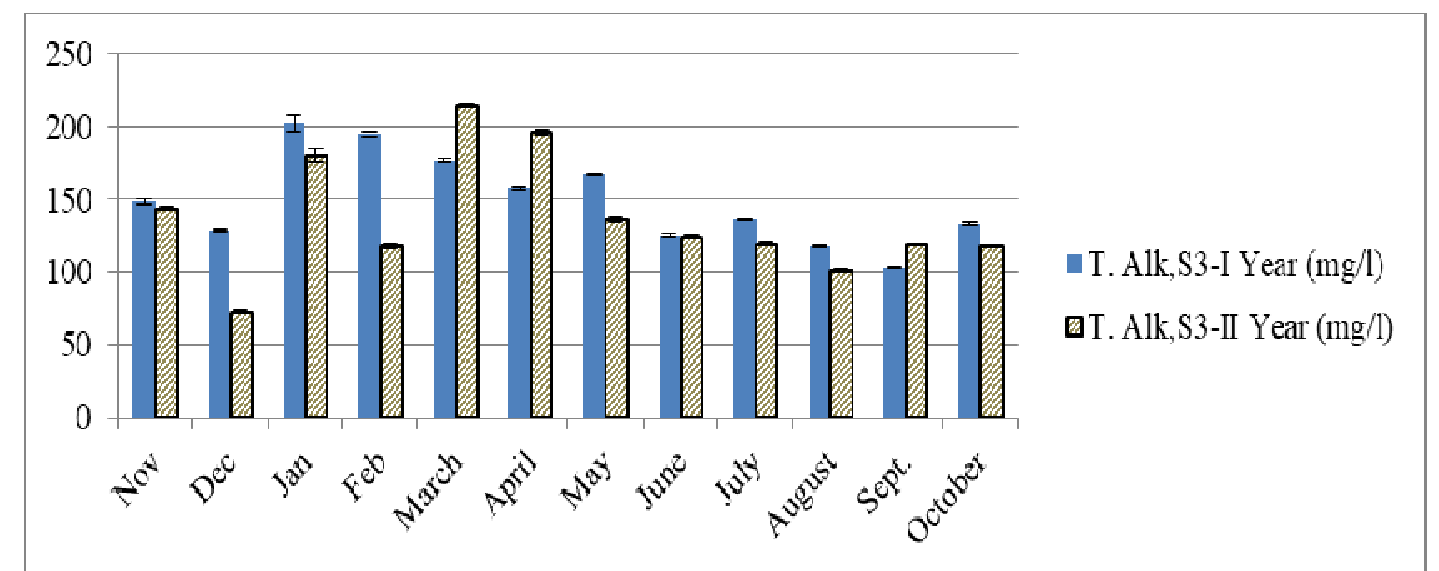

Figure 3. Monthly variations in TA at Tarahara Fish Farm during the first and second year study periods (Nov. 2008- Oct. 2010). 


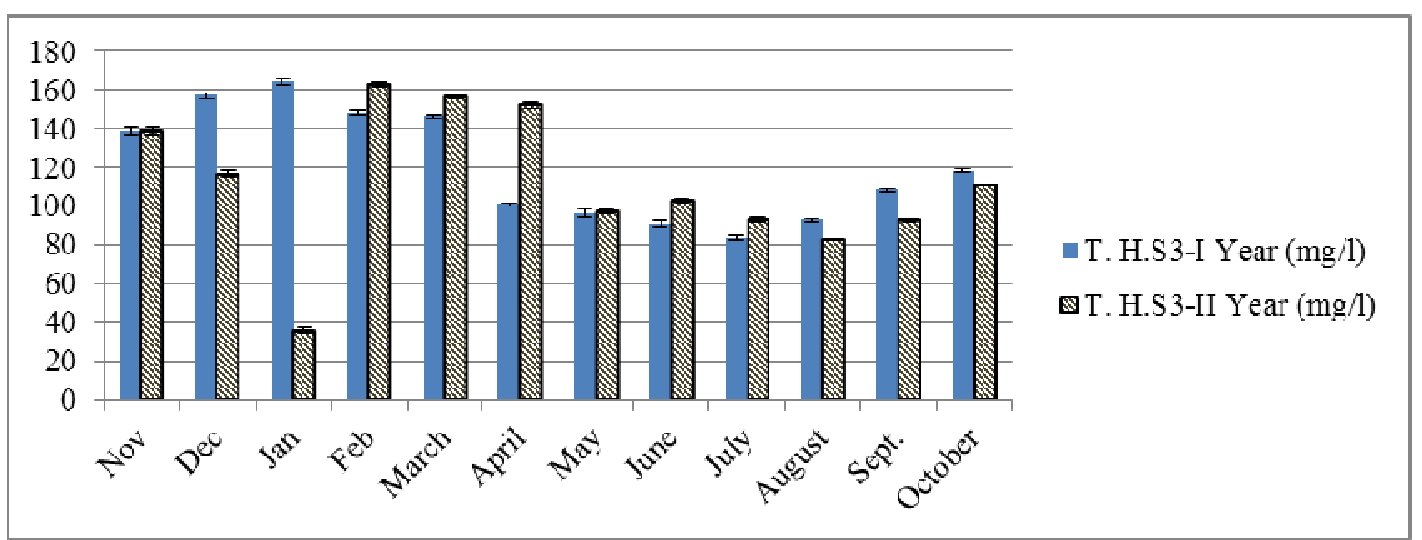

Figure 4. Monthly variations in T.H. at Tarahara Fish Farm during the first and second year study periods (Nov.2008- Oct. 2010).

\section{Conclusion}

Physico-chemical parameters significantly $(\mathrm{P}<0.01 ; 0.05)$ differed in different months. Although the water quality parameters were within suitable range for the fish growth and breeding, the periodic monitoring is required to avoid any alterations of its natural environment for the maximum production of fish. Tarahara fish farm has greater importance being its location in fish super zone. It has to be developed one of the leading technical manpower producers for fish farming team of eastern Nepal.

\section{Acknowledgements}

The first authors was very much thankful to authorities of R \& D Lab of Central Campus of Technology, Dharan; Ecotoxicology lab, Zoology Department, North Bengal University; and SEAM-N lab, Biratnagar for providing water analysis facilities.

\section{References}

APHA, AWWA \& WEF. 2012. Standard methods for examination of water and wastewater $\left(22^{\text {nd }}\right.$ ed.). American Public Health Association, American Water Works Association and Water Environment Federation. Washington D.C., USA.

Aryal, S. \& P. Lacoul 1996. Water quality and diversity of diatoms in Punyamati River, Nepal. Ecoprint 3: 45-49.

Bais, V.S., N.C. Agrawal \& A. Tazeen 1995. Comparative study on seasonal changes in phytoplankton community in the Sagar Lake and Military Engineering Lake (M.P.). $J$. Freshwater Biol. 7: 19-25.

Barat, S. \& P. Jha 2002. Changes in the water quality and total coliform bacterial load in a stretch of river Mahananda at Siliguri city, West Bengal. Asian J. Microbiol. Biotech. Env. Sc. 4: 571-575.

Bhatt, R.P. \& S.N. Khanal 2011. Impoundment after damming the Rivers change in flow regime and effect in water quality of Chilime Hydropower Project in Rasuwa District, Nepal. Adv. Biores. 2: 33-39.

Bhowmick, B.N. \& A.S. Singh 1985. Effect of sewage on physico-chemical characteristics and bacterial population in river Ganga at Patna. Ind. J. Ecol. 12: 141-146. 
Bose, S.K. \& A.C. Gorai 1993. Seasonal fluctuations of plankton in relation to physicochemical parameters of a freshwater Tank of Dhanbad, India. J. Freshwater Biol. 5: 133140.

Chakraborty, R., D.P. Roy \& S.B. Singh 1959. A quantitative study of the plankton and physico-chemical conditions of the river Jamuna at Allahabad in 1954-55. Indian J. Fish. 6: $186-203$.

Elmore, H.L. \& W.F. West 1961. Effect of water temperature on stream reaeration. J. Sanit. Eng. Div. ASCE 87: 59-71.

Gautam, A. 1990. Ecology and pollution of mountain waters. Ashish Publishing House, New Delhi.

Hutchinson, A.H., S.C. Zucas \& M. McPhail 1992. Seasonal variation in the chemical and physical properties of the waters of the states of Georgia in relation to phytoplankton. Trans. Roy. Soc. Canada 3: 177-183.

Jhingran, V.G. 1991. Fish and fisheries of India ( $3^{\text {rd }}$ ed.). Hindustan Publ., New Delhi.

Jindal, R. \& R. Kumar 1993. Limnology of a freshwater pond of Nalagarh (Himachal Pradesh, India). 1. Physico-chemical complex. In: Advances in Limnology (Ed. H.R. Singh). Narendra Publishing House, Delhi. pp. 107-112.

McEachern, P. 1994. Limnology and the natural wetlands survey. In: Safeguarding wetlands in Nepal (Eds. B. Bhandari, T.B. Shrestha \& P. McEachern). IUCN, Nepal. pp. 89-103.

Mishra, A.P., B.K. Bora \& M. Sharma 1998. Investigations on the seasonal variation of certain physico- chemical parameters of a Beel, Assam, India. J. Freshwater Biol. 10: 83-87.

Mishra, A.P., B.K. Bora \& M. Sharma 1999. Limnological investigation of a freshwater tributary Assam, India. J. Freshwater Biol. 11: 1-5.

Moitra, S.K. \& B.K. Bhattacharya 1965. Some hydrobiological factors affecting plankton production in fish pond at Kalyani, W.B., India. Ichthyol. 4: 8-12.

Niroula, B., K.L.B. Singh, G.B. Thapa \& J. Pal 2010. Seasonal variations in physico-chemical properties and biodiversity in Betana Pond, Eastern Nepal .Our Nature 8: 212-218.

Pahwa, D.V. \& S.N. Mehrotra 1966. Observations on fluctuations in abundance of plankton in relation to certain hydrobiological conditions of river Ganga. Proc. Natl. Acad. Sci. India 36 B2: 57-189.

Palharya, J.P. \& S. Malviya 1988. Pollution of the Narmada at Hoshangabad in Madhya Pradesh and suggest measure for control. In: Ecology and pollution of Indian Rivers (Ed. R.K. Trivedy). Ashish Publishing House, New Delhi. pp. 55-86.

Pandey, K.K. \& M.S. Lal 1995. Limnological studies of Garhwal Himalayan hill stream Khandagad: Seasonal fluctuation in abiotic profile. J. Freshwater Biol. 7: 7-11.

Patralekh, L.N. 1994. Comparative account of physic-chemical properties of three fresh water ecosystems. J. Freshwater Biol. 6: 115-119.

Rawat, M.S., C.P. Juyal \& R.C. Sharma 1995. Morphometry and physico-chemical profile of high altitude lake Deoria Tal of Garwal Himalaya. J. Freshwater Biol. 7: 1-6.

Sharma, U.P. 1996. Ecology of the Koshi River in Nepal-India (North Bihar): A typical river ecosystem. In: Environment and Biodiversity: In the context of South Asia (Eds. P.K. Jha, G.P.S. Ghimire, S.B. Karmacharya, S.R. Baral \& P. Lacaul). Ecological Society (ECOS), Kathmandu, Nepal. pp. 92-99. 
Shrestha, J., D.M. Singh \& T.B. Saund 2009. Fish diversity of Tamor River and its major tributaries of Eastern Himalayan Region of Nepal. Nepal J. Sci. Tech. 10: 219-223.

Singh, H.P. 1990. Distribution and seasonal fluctuation of certain physico-chemical features in the Brahmaputra River. J. Assam Sci. Soc. 32: 64-69.

Singh, M. 1995. Impact of human activities on the physico-chemical conditions of two fish ponds at Patna, India. J. Freshwater Biol. 7: 13-17.

Swarup, K. \& S.R. Singh 1979. Limnological studies on Suraha lake (Ballia). J. Inland Fish. Soc. India 11: 22-23.

Thapa Chhetry, D. \& J. Pal 2011. Physico-chemical parameters of Koshi River at Kushaha area of Koshi Tappu Wildlife Reserve. Our Nature 6: 16-25.

Thapa, G.B. \& J. Pal 2012. Studies on some physicochemical parameters of Baidya and Itahari Municipality fish ponds, Nepal. NBU J. Anim. Sc. 6: 26-39.

Thapa, G.B. \& J. Pal 2014. Evaluation of physico-chemical characters of Singhia and Budhi rivers in Sunsari and Morang Industrial Corridor, Nepal. Int. J. Adv. Res. Biol. Sci. 1: 104-112.

Trivedy, R.K. \& P.K. Goel 1986. Chemical and biological methods for water pollution studies. Environmental Publications, Karad, Maharashtra, India.

Trust, T.J. 1986. Pathogenesis of infectious disease of fish. Ann. Rev. Microbiol. 40: 479-502. 